\title{
The joy of learning: Feminist materialist pedagogies and the freedom of education
}

\author{
Maria Tamboukou
}

\begin{abstract}
In this article, I trace lines of materialist pedagogies in the history of women workers'education following feminist interpretations of Spinoza's assemblage of joyful affects. More particularly, I focus on the notions of laetitia [joy], gaudium [gladness] and hilaritas [cheerfulness] as entanglements of joy and trace their expression in practices and discourses inscribed in archival documents that I have reassembled around the theme of women workers' education. My reading of Ethics follows a range of feminist thinkers that have engaged with Spinoza's 'ethics of joy' in education and beyond. The article draws on extensive archival work with personal auto/biographical documents and public essays of women workers/educators/writers in Paris and New York that span the period between 1830 and 1950. What I argue is that it is the experience of creative and radical education that has created a platform for workers to re-imagine themselves in the world with others.
\end{abstract}

Key words: ethics of joy; materialist pedagogies; women workers' education; imagination; freedom

\begin{abstract}
Providence was kind and led my feet to a Summer School in Bangor, North Wales, organised by the W.E.A in conjunction with the Extra-Mural department of Manchester University [...] The various seminars were small but spirited; the tutors understanding and encouraging [...] It was a strange joy to browse over the niceties of Bishop Blougram's Apology or to delve into the intricacies of The Ring and the Book [...] It was a month of almost complete happiness; a pinnacle of joy never to be quite reached again. (Foley, 1973, pp. 91, 92)
\end{abstract}

In the last two pages of her autobiography, A Bolton Childhood (1973), British labour activist Alice Foley chose memories of joy and happiness of her first summer school in workers'education to conclude the account of her early life. Her text forcefully expresses entanglements between 
ethics, aesthetics and politics in women workers' lives. As I have shown elsewhere (Tamboukou, 2017), Foley's educational experience makes connections with a wider international network, the movement for workers' education that was catalytic in the history of the labour movement, as well as women's position within it, and made radical interventions in the economic, social and cultural formations of the twentieth century.

Focusing on Foley's joyful experiences of education, in this article, I follow lines of feminist materialist pedagogies through Spinoza's philosophical assemblage of joyful affects. More particularly, I look at the notions of joy [laetitia], ${ }^{1}$ cheerfulness [hilaritas], pleasure [titillation] and gladness [gaudium] and I trace their material and corporeal expressions in practices and discourses inscribed in'documents of life' (Plummer, 2001) that I have reassembled around the theme of women workers' education. My reading of Ethics follows Lloyd's excellent study (1996), as well as a range of feminist thinkers who have engaged with Spinoza's 'ethics of joy' in education and beyond (see Gatens, 2009). I argue that the experience of radical education has created a platform for women workers to re-imagine themselves in the world with others. The article unfolds in two parts: (a) first, I reread the Ethics, focusing on ideas and concepts that are most relevant to feminist neomaterialist approaches to education ${ }^{2}$; (b) then I look at how such concepts, fleshed out in women workers' narratives, can map a new plane of educational praxis. By way of conclusion, I consider education as a component of Spinoza's take on freedom within current concerns and debates in educational studies.

\section{Thinking with Spinoza}

Because human bodies are capable of a great many things, there is no doubt but what they can be of such a nature that they are related to minds, which have a great knowledge of themselves [...] but for a clearer understanding of these things, we must note here that we live in continuous change, and that as we change for the better or worse, we are called happy or unhappy [...] In this life then, we strive especially that the infant's body may change (as much as its nature allows and assists) into another, capable of a great many things and related to a mind very much conscious of itself, of God, and of things. [E VP39S]

In commenting on Spinoza's reflections on the joy of living a life of knowledge and understanding, Lloyd critically observes that, apart from the above extract in the fifth part of the Ethics, there is very little explicitly educational in Spinoza's writings $(1998,157)$. Reflecting on the possibilities of bodies and minds to effectuate change, Spinoza implicitly refers to the educational actions that can change 'the infant's body'to a mind/body that understands the world and their position within it. What is particularly striking in this extract is the agonistic character of transformation: 'we strive' [conamur] Spinoza writes in relation to the whole process. I want to stay in this agonistic 
character of the educational process, as a transition to greater activity, particularly linking it to Dahlbeck's (2015) suggestion of using insights from Spinoza's philosophy to look at education as resistance, a process of guiding students towards the gradual formation of adequate ideasthe Spinozist path to freedom par excellence. In the case of workers' education, 'resistance' is always, already there, ipso facto, given the material and cultural conditions of its possibility.

Spinoza's idea of education as a joyful agonistic process brings in imagination, active affects, reason, the gradual formation of adequate ideas and ultimately intuitive understanding, as the highest level of knowledge, and therefore happiness, in the philosopher's ethical universe. Joy as an educational experience takes different forms of expression when considered in the context of associations and 'collective imaginings' (Gatens \& Lloyd, 1999). As Ruddick has noted from a Spinozistic perspective, there is a connection between joy and empowerment, in that 'we organise encounters to maximise joy' (2010, p. 22). In Spinoza's philosophical universe, humans collaborate with one another to enhance their power for action; this is not suggested as a moral proposition-humans should collaborate-but as a matter of fact, an immanent process of how things work, changes happen and the world moves forward. Drawing on Spinoza's theory of how bodies are in a continuous process of affecting and being affected, Gatens and Lloyd have argued that freedom is an ethicopolitical practice, 'a collective process of becoming-free' (1999, p. 146).

Moreover, possibilities for action are relational and emerge as the expression of affective and cogni- tive interrelations. In this context, students make the transition from the phase of understanding through forming adequate ideas to the experience of feeling joy, which eventually motivates the Spinozistic scientific intuition of getting to know the world and their relation to it. This process of knowledge-inbecoming, as I will call it, is further linked to the expression and enactment of political discourses and practices, a powerful assemblage in workers' education that emerged through the struggles of the labour movement and had social change at its heart.

We can therefore see that although 'education' is not explicit in Spinoza's plane of thought, it is nevertheless closely connected to its dominant philosophical themes as identified by Lloyd: 'the unity of a reality which nonetheless undergoes a myriad of transformations; the dynamic character of bodies, minds and ideas; the transformation of emotions through understanding them' (1996, p. 4). Imagination is crucial in all of these themes and takes a central role in the attempt to think about education through Spinozistic lenses. Let us then consider imagination first, as initiating the process of knowledge-in-becoming.

Imagination has been widely discussed as an ambiguous concept in the rich body of literature around Spinoza's Ethics, but it is at the heart of 
his philosophical thought, as clearly and succinctly captured in the opening proposition of Part IV of the Ethics: 'Nothing positive which a false idea has is removed by the presence of the true insofar as it is true' [E, IVP1]. As a rationalist philosopher, Spinoza is cautious about the 'errors' of imagination but he does not dismiss it as irrelevant to epistemological enquiries. In his view, imagination is an ineradicable component of human life and of knowledge itself and shapes the way he views the world, subjects and their interrelation. According to Lloyd, it is precisely Spinoza's take on imagination that makes connections with educational discourses and practices:

It is in his thoughts on imagination-its hazards and its enormous potentials for ethical pedagogy in relation to both individual and social life-that we find what can be mostly fruitfully appropriated from his philosophy for rethinking educational objectives and practices in the present. $(1998$, p. 157)

Reason and imagination are not incompatible in Spinoza's philosophy. As Lloyd pithily notes, "fictitious or "feigned" ideas are mixed methods of knowing. They partake of imagining, but through being criticised by reason they become a source of improved understanding' (1996, p. 61). This is because Spinoza's take on imagination emerges from the immanent connections between minds and bodies, as well as his famous treatment of the mind as an idea of the body: "the object of the idea constituting the human mind is the body. Or a certain mode of extension which actually exists, and nothing else' [E IIP13].

Negri (1991) has particularly focused on the 'savage power' of imagination in knowledge formations, as well as in the constitution of the real: "imaginative knowledge experiences the affections of the body, of exteriority, of duration, with the intensity that follows phenomenologically from them' (1991, p. 80). In this light,

imagination becomes something more than a source of error, to be transcended [...] Reason can criticise those fictions, replacing them with better ones. The goal is not to transcend and spurn imagination, but to complement it and collaborate with it. (Lloyd, 1996, p. 63)

Imagination thus remains in Spinoza's epistemological toolbox and Etienne Balibar has argued that 'in reality all men are in both the world of imagination and that of reason [even when they have] acquired many true ideas through science and philosophy' (1998, pp. 109, 110). In Balibar's interpretation, the mind never operates in abstraction, but always in reference to the body of which it is the idea and thus it is always entangled in the bodily affects and passions. Moreover, bodies/minds never act in isolation. When we join forces by coming together as associations or collectivities, we enhance our power as embodied and embedded individuals and we are more prone to be 
affected by joy. In this light, perfec- tion for Spinoza should not be taken as individualistic, but is rather a process of becoming active and autonomous through closer association and friendship with others (Balibar, 1997, pp. 24, 25). Balibar's influential reading of Spinoza has brought forward transindividuality as a particularly important way of theorising subjectivity. Understood as 'the mutual constitution of individuality and collectivity’ (Read, 2015), transindividuality is a useful concept to theorise the emergence of 'the subject of education' through Spinozistic lenses, particularly so within the agonistic context of workers' education.

It is therefore 'in the social dimensions of Spinoza's version of imagination that we can find the most illuminating applications of his philosophy to education and social critique' (Lloyd, 1998; p. 160). Grassi has further argued that the Spinozistic process of working through affect, a process engaged by the act of imagining, is a way of getting into the essence of what it is to live, and it is thus central in selfunderstanding and self-determination (2009, p. 148). Grassi's pithy observation makes a powerful link to joy, the Spinozistic active affect par excellence and a crucial component in the process of knowledge-inbecoming.

It is in Part III of the Ethics that Spinoza brings imagination and passions together in considering 'human actions and appetites' ( $E$ IIIPREF). Passions are included in the geometric order of the Ethics and in the Definitions Spinoza marks an important difference between 'affections' [affectio] and 'affects' [affectus]:

By affect I understand affections of the body by which the body's power of acting is increased or diminished, aided or restrained, and at the same time, the ideas of these affections.

Therefore, if we can be the adequate cause of any of these affections, I understand by the affect an action, other- wise, a passion. [E IIID3]

Deleuze has pointed to the fallacy of simply assigning affection [affectio] to the body and affect [affectus] to the mind: 'The affectio refers to a state of the affected body and implies the presence of the affecting body, whereas the affectus refers to the passage from one state to another' (1988, p. 49). In Deleuze's understanding, affections are associated with images and affects with feelings: 'there is a difference in nature between the image affections or ideas and the feeling affects, although the feeling affects may be presented as a particular type of ideas or affections' (1988, p. 49).

Affects in Spinoza's framework can be active or passive, Lloyd has commented (1996, p. 73), while joy is 'the passion by which the mind passes to a greater perfection' [E IIIP11S]. Joy is thus tightly interwoven with the crucial concept of conatus as the essence of all beings-humans and non-humans. Lloyd has further noted that 
although joy is one of the three primary affects in the geometrical exposition of desire [cupiditas], joy [laetitia] and sadness [tristitia], it is not perceived as a single concept, but rather as an entanglement of active affects, including cheerfulness [hilaritas] and gladness [gaudium], amongst others (1996, p. 90). Looking closely at the entanglements of joy, Lloyd has explained that gladness 'accompanies a thing's distinctive pleasures' (1996, p. 90), while cheerfulness 'is a pleasure of reflection [that] arises from the mind's capacity to hold the fragments of consciousness together in a whole not confined to the present' (p. 90). Cheerfulness is 'a higher order of joy': it unfolds within a durée and 'it is more easily conceived than observed'[E IVP44S]. Given the distinctiveness of cheerfulness and its relation to eternity, it is no wonder that Spinoza expands on this concept in part four of the Ethics, which is about 'human bondage' and the power of affects to restrain, but also to enable the mind/body assemblage to make the transition from bondage to freedom-the topic of the fifth part. Cheerfulness as a component in the assemblage of joy is thus most tightly related to reason and knowledge.

'We act only insofar as we understand'(E IVP24D), Spinoza has famously written. Greater understanding gives subjects an increased sense of feeling their power and this empowering process also enacts a new source of joy. Drawing on the circular relation between joy, empowerment and action, Rorty (1987) has made a useful distinction between individuation and individuality in how we configure the role of reason, knowledge and understanding in Spinoza's philosophical universe. According to Rorty's interpretation, forming adequate ideas of our passions and the world is a process that gradually erases differences between individuals: individuation diminishes as humans act together in agreement. It is the same process of reasoning that increases their individuality however, as they gradually realise their power of acting and persevering; that is, their individual conatus.

In the light of the above, Gatens has suggested that 'one can read the Ethics as a philosophy of power that offers a fluid and immanent ethics of joyful and life enhancing encounters' (2009, p. 202). Aloni has further focused on happiness as crucial for a Spinozist liberating and empowered pedagogy (2008, p. 533). Although Spinoza celebrates sensual pleasures and material happiness, however, it is 'intellectual love' that makes the difference in his Ethics, a point that leads to the consideration of his tripartite articulation of knowledge.

Spinoza's view of knowledge includes imagination, reason and intuition: 'Knowledge of the first kind is the only cause of falsity, whereas knowledge of the second and of the third kind is necessarily true' [E, IIP41]. As imagination encompasses 'knowledge from random experience' [E, IIP40S2], it can only form inadequate and confused ideas. It is only in the second kind of knowledge that the mind can 
have 'common notions and adequate ideas of the properties of things' [E, IIP40S2]. It is the assemblage of such 'common notions' that Spinoza defines as 'reason', but in this second order of knowledge the world is still perceived in terms of 'ontologically discrete categories' (Donovan, 2009, p. 175). It is only when we have made the transition to the third order of knowledge that we reach the level of 'intuitive knowledge', which 'proceeds from an adequate idea of the formal essence of certain attributes of God to the adequate knowledge of the essence of things' [E, IIP40S2]. In Lloyd's succinct summary:

The first way of knowing is focused on singular things, but is inherently inadequate. The second is inherently ade- quate, but unable to grasp the essence of singular things. The third and highest kind of knowledge is inherently adequate and able to understand singular things. (1996, p. 67)

It is precisely the entangled relationship between these three levels of knowledge that has triggered controversial interpretations: (a) the traditional Hegelian route of Spinoza's strict rationalism and (b) a more complex view of the relations between imagination and reason that Antonio Negri has initially proposed, with Lloyd, Gatens and Balibar following it, amongst others. What is particularly interesting, however, in Spinoza's tripartite system of knowledge is how affects are forcefully interwoven in his epistemology. As Donovan has commented,

Spinoza believes that we attain higher levels of knowledge and joy by understanding the adequate causes of ideas and by having a body that is productively engaged in the world. The higher our level of knowledge and affectivity, the greater our joy. (2009, p. 177)

The body is crucial here as 'the ground of human action' and as Donovan has further suggested: 'the mind is constituted by the affirmation of the actual existence of the body, and reason is active and embodied, precisely because it is the affirmation of a particular bodily existence' (2009, p. 179, original emphasis). Perceived beyond the mind/body dichotomy, reason emerges in its splendid materiality and situatedness, always within the second level of knowledge. Moreover, since Spinoza has argued that a political body is always an effect of its citizens' lived experience, we can extrapolate this to an educational community and argue in parallel that the 'body' is always dependent on the educational subjects' corporeal and affective experiences. This is where Gatens and Lloyd's notion of 'collective imaginings' (1999) becomes so pertinent, particularly in relation to workers' education. 
I have very few experiences of the joys of childhood or the games of the early years. From the time I learned to read, reading became my only occupation and the charm of all moments. I felt a vague desire to experience and know everything [...] Still too young to grasp my social position, I was happy [...] but these flattering dreams would soon faint. The necessity of work, made me understand that deprived of wealth, I had to renounce knowledge, happiness, I resigned to myself. 3

In this moving section from her Profession of Faith, a rich and powerful text sent to the Saint-Simonian newspaper, the Globe, around 1832, Jeanne Deroin (1805-1894) forcefully expressed her love and pas- sion for knowledge, as well as her disappointment about not being able to get an education. Deroin was born and brought up in Paris as a proletarian girl. She worked as a seamstress to earn her living, but she eventually became a self-taught worker intellectual. Through her involvement in the romantic socialist movements of nineteenth-century Europe, she realised her dream of becoming a teacher and a journalist. As Deroin's early testament reveals, education has always been a project and a dream at the heart of many workers' lives, both men and women, from the beginning of industrialisation. I have written elsewhere about the history, practices and discourses of this movement (see Tamboukou, 2017), but what I want to do in this section is discuss how it was saturated by joyful affects.

Deroin's autobiographical reference to education fleshes out the assemblage of desire/reason/imag- ination that I discussed above. It also very much highlights the agonistic character of the educational transformation as expressed in Spinoza's rare reference to education in the fifth part of the Ethics [E VP39S]. In writing her Profession of Faith and bravely presenting it to the intellectuals of the Saint- Simonian community, Deroin not only showed the power of imagination in motivating a proletarian girl to educate herself, but also revealed that the transformation to perfection is an ongoing process, a knowledge-inbecoming. Moreover, it was through her immersion in the utopian collectivities of nine- teenth-century France that Deroin realised her dream of getting an education and thus increased her power to act. As Gatens has suggested, 'Spinoza's political writings allow us to think about human relations [...] in terms of sociabilities and communities [...] while his developmental account of knowl- edge implies not only different ways of knowing but also corresponding ways of being' (2009, p. 189).

Marie-Reine Guindorf (1812-1836), a self-educated seamstress, who worked alongside Deroin in the editorial collective of the first autonomous feminist newspaper in France, wrote about the power of associations: 
that the order of the future will be to draw upon association. At this moment human beings of all parts associate to make their opinions prevail; we women should also spread our ideas to make people understand that our EQUALITY with the man, far from lowering them, as some seem to believe, will be on the contrary a pledge of happiness for all. 4

While working hard during the day, Guindorf joined the Association of People's Education and devoted her free time in the evenings to the education of 'the daughters of the people' (see Tamboukou, 2015). What is beautifully articulated in her article is the power of association in congealing moments of change, joy and happiness in the flow of educational and political transformation. Human striving for Spinoza involves its association with other bodies since it is through such entanglements with others that one's power is increased and joyful bodies emerge. In this light, Deleuze has suggested that reason in Spinoza's plane of thought is 'the effort to organise encounters on the basis of perceived agreements and disagreements' (1990, p. 280) and it is precisely this effort that leads to associations. As Spinoza writes in his Theologico-Political Treatise: 'men are not born to be citizens but are made so' (TP V61). Gatens has further remarked that through Spinozist lenses human freedom is only possible within a civil society and it is thus 'a collective endeavour' (2009, p. 194); it is about understanding our situation 'and on the basis of such understanding, to act to maximise our power and our joys'. (p. 195) But in order for freedom to become a feasible project, the state, according to Spinoza, should create at least two fundamental conditions of possibility: a political climate of pluralism and tolerance and an education system that could help people navigate through the three levels of knowledge outlined in the Ethics. Spinoza's theory of knowledge has initiated a line of progressive pedagogical thinkers such as A. S. Neill, John Dewey and Bertrand Russell, amongst others (see Aloni, 2008, p. 539). Here I am particularly interested in Spinoza's influence upon Dewey's thought since he was a central figure in the movement for workers' education in the US, particularly as he kept highlighting joy, vitality and happiness as central aims of a humanist and progressive educator. His notion of 'creative imagination' mobilised discourses that underpinned the philosophy, vision, curricula and practices of workers' education. This radical education movement was mainly organised, run and sustained by women workers, like Fannia Mary Cohn (1885-1962), who served the educational department of the International Ladies' Garment Workers' Union (ILGWU) for almost 50 years (1918-1962). Cohn was deeply interested in the power of creative imagination to open up the dark side of things, reveal hidden meanings and remake the world anew (see Tamboukou, 2017). It was in the context of such ideas that she was in correspondence with

Dewy and often invited him to give lectures at the workers' university in New York. 
In their auto/biographical writings, women workers have variously expressed moments of joy, happi- ness and bliss experienced while attending classes and summer schools. Enjoyment was indeed at the heart of women workers' education, as a movement aiming 'to develop a desire for study as a means of understanding and of enjoyment in life' (Smith, 1929, p. 7). This 'ethic of joy' (Lloyd, 1996) sprang from an assemblage of 'materialist pedagogies' (Hollis, 2004) that I now want to map on the plane of Spinoza's joyful affects.

In writing about her experiences at the Bryn Mawr school for women workers in the industry, Rose Pesotta (1896-1965), an anarchist labour organiser, remembered the beautiful campus: 'most of our classes are held under shady green trees on beautifully kept lawns', she wrote (1987[1944], pp. 15, 16). The pleasures of nature came hand in hand with new knowledge and understandings about labour economics, social and political history, as well as art education. Literature, poetry and drama were indeed crucial in workers' education, but were organically entangled with the theoretical and science strands of their curriculum. Indeed, an important aspect of the Bryn Mawr pedagogy was a thematic and interdisciplinary approach to teaching and learning, with courses that were drawing on themes, questions and problems relevant to the students' needs, interests and experiences, rather than driven by strict disciplinary boundaries or contents.

Hollis (2004, p. 22) has given a very succinct example of how this pedagogy worked. Supposing the chosen topic was wage determination in textile mills: an economic analysis would show how profit is generated by explicating and discussing various theories of value; a historical study would explore how wages had evolved in the US or European industry; and finally creative writing might be employed to allow students express and reflect upon their own experiences. What is particularly notable about the Bryn Mawr pedagogical practices is that in grappling with the women workers' academic deficiencies, the faculty tutors found a valuable alternative by drawing on the richness of students' lived experiences as a departure point for the discussion and analysis of social and economic issues. The following state- ment from Jeanne Paul, a Bryn Mawr student, powerfully shows why 'an intelligent understanding of life' was so important for women workers:

Literature means to me the key to realms of beauty, dreams and fantasies [...] Sometimes, in the land of Poetry, I would meet with glorious sunsets, exquisite flowers, singing birds, storms on sea and on land [...] Sometimes in the land of Novels, I would see strange peoples, witness struggles between heart and mind [...] My possessing this magic key somewhat made up for my dull world. 5

Jeanne Paul's account of what literature meant to her beautifully expresses the power of imagination in allowing the subject of education to run away from the monotony of working life. Her 
imaginative leap to 'the strange lands' of Poetry and Novels was a phase in the process of transforming herself through learning. As already noted above, 'fictions give access to adequate ideas without being themselves adequate' (Lloyd, 1996, p. 61). In this light, Jeanne Paul's imaginary travels helped her rework her lived experiences, see them in a different light and ultimately understand the source of her anxiety and dis- content. We need to remember here that understanding is crucial in the transformation of emotions for Spinoza, but it is also at the heart of his conceptualisation of politics: 'I have taken great care not to deride, bewail, or execrate human actions, but to understand them' [PT 14] he wrote in his Political Treatise. It is in the process of understanding the drudgeries of her life that Jeanne Paul educates herself in the history and economics of the labour movement and this new way of seeing herself in the world with others elates and excites her. As already noted in the previous section, joyful affects are entangled with cognitive understanding and the power to reason as they enhance the subject of education to act, rather than being acted upon. This possibility of action is central in Spinoza's idea of freedom: 'That thing is called free which exists from the necessity of its nature alone and is determined to act by itself alone' [E ID7].

Bryn Mawr students have vividly expressed gladness [gaudium] in reflecting upon moments in their education when they realised that they could understand labour economics and could therefore see why they were exploited and, most importantly, how they could resist. This is how Carmen Lucia remembers the day she understood the notion of economy, commodity and selling one's labour. As she talks with a friend in front of the camera, for the Bryn Mawr documentary film 'Women of Summer', her face beams:

Did you ever have Amy Hews in the classroom? Do you remember the morning she said 'how many of you think that the laundry is a factory?'We all were stunned: 'Well the laundry is not a factory, all they do is wash clothes'[...] but she insisted [...] it finally turned out, sure, I am selling my labour ...'oh, she said, you mean you are a commodity?' Then we got the first inkling of what economy and what social problem means [sic] when you sell your labour, that's when the question of the union came in. 6

Lucia's face beams with gladness when she connects the understanding of selling one's labour with the necessity of resistance through trade unionism, her personal road to freedom, as it unfolds in her memories. Women workers' auto/biographical documents became important literary tools through which they rewrote themselves in discourse and culture. Moreover, the beauty of the Bryn Mawr campus made them cheerful and this active affect of hilaritas inspired them to be involved in the Workers' Theatre Movement, which was at its heyday in the first half of the twentieth century (see 
Samuel, MacColl, \& Cosgrove, 1985). The archives of the Bryn Mawr summer school and the ILGWU's educational archive include a rich range of photographs that carry visual traces of the students' hilaritas, most forcefully expressed in the plays they wrote, directed and acted in (see Tamboukou, 2017).

The joy of education made forceful connections with the playfulness of the drama genre. Here it is important to note that an important trait of the workers' theatre, as compared with mainstream drama performances, was the blurring of the distinctions between 'spectators' and 'actors', creating a milieu of participation that left a long-lasting impression upon the Bryn Mawr student, Victoria Grala. Her account of the 'technique' used to mingle actors and audience brings forward the importance of the pedagogies of theatre education as a joyful corporeal practice of forming and reforming collectivities:

A unique and somewhat startling technique which was used over and over again in our drama this summer, was that of actors speaking from different parts of the audience ... We discovered that an emotional feeling of unity resulted from such drama. (in Hollis, 2004, p. 96)

James (2011) has looked at the question of how communities can make the transition between imagin- ing and reasoning, thus attaining the second kind of knowledge in Spinoza's tripartite system. Focusing on this transition is particularly relevant to questions and issues arising from workers' education, since this was a cultural movement springing from industrial communities and political associations. We could see this working in the materialist pedagogies deployed in women workers' education and particularly in how the workers' rich experiences in the industry were counterposed with their initial lack of academic background.

\section{Education as a process of becoming free}

In looking at marginalised histories and narratives in this article, I have made connections between Spinoza's ethic of joy and his tripartite system of knowledge within the assemblage of women workers' education. Drawing on Spinoza's ideas about the capacity of bodies to undergo changes and to increase their power to understand and to act through affective encounters, I have shown how feminist materialist pedagogies played a catalytic role in providing material, spatial and intellectual platforms that sustained and supported processes of preservation, affirmation and continuous transformation. Education has been mapped as an agonistic plane wherein imagination, reason, understanding and joy are entangled in the process of becoming free.

Deleuze's reading of Spinoza has been particularly influential in this context. Theorising Spinoza's conatus, Deleuze has brought forward 
the idea of becoming rather than being free: 'man is not born free, but becomes free or frees himself' $(1988$, p. 70$)$. It is this process of becoming free, through feeling, imagining, understanding and acting, that the deployment of feminist materialist pedagogies has facilitated. Through being transferred to 'different spaces' and 'other times', women workers were temporarily released from real life worries, obligations and constraints and were inspired to think and act differently. Their lived experiences became the material basis of their educational adventure; theoretical abstractions were discarded in favour of grounded understandings and situated knowledge; creative educational practices encouraged them to re-imagine and indeed reposition themselves in the world with others; active affects followed the formation of adequate ideas and women workers 'took possession of their power of acting', to paraphrase Deleuze (1988, p. 70). Freedom for women workers was not a state to be attained, but rather an adventure, an experiment in life, a process of becoming through understanding, action and affective encounters.

Affect in education is a highly discussed theme in contemporary debates, but it is also sadly becoming a faraway planet in relation to educational praxis. As educators and/or students, we are instead encouraged to think about the politics and economics of emotions, with emotional intelligence becoming a frightfully dangerous educational discourse (see Tamboukou, 2003). Spinozist insights in educational philosophy and praxis can thus contribute to current neo-materialist pedagogies and post-humanist approaches in an attempt to reconceptualise education as an open process of feeling the world and becoming free.

\section{Notes}

1. It has to be noted here that laetitia has been translated as pleasure, by Boyle (Spinoza, 2002) and Shirley (Spinoza, 1982), as well as elation by Rorty (2009) and there is a vibrant debate around translating Spinoza's affects/emotions [affectuum]-a debated translation in itself.

2. For an overview of the burgeoning literature in this field see amongst others Taylor \& Hughes, 2016, as well as two special issues in the journal Gender and Education, 'Material Feminisms, New Directions in Education' (Vol. 25, 2013-Issue 6) and 'Shifting education's philosophical imaginaries: relations, affects, bodies, materialities' (Vol. 28, 2016-Issue 2).

3. Bibliothèque Nationale de France/ Bibliothèque de l'Arsenal/ Fonds Enfantin ou Fonds Saint-Simonien/ MS7608/ Correspondance du Globe (Dames)/ Deroin (Mme)/ Profession de foi/22 (1-44), (BnF/BdA/FE/MS7608/CdG/ Deroin/22). Also, transcribed in Riot-Sarcey 1992, 128.

4. Tribune des Femmes-La Femme Nouvelle, 1(15), 198-199, April, 1833 [all emphases in the original].

5. Jeanne Paul, 'What literature means to me', Bryn Mawr Light, 1926 (in Hollis, 2004, pp. 149, 150).

6. Carmen Lucia, a Bryn Mawr students talking in the film 'Women of Summer' (Heller \& Bauman 1985). Availble on line: 


\section{References}

Aloni, N. (2008). Spinoza as educator: From eudaimonistic ethics to an empowering and liberating pedagogy. Educational Philosophy and Theory, 40(4), 531-544.

Balibar, E. (1997). Spinoza: From individuality to transindividuality. Delft: Eburon. Print. Retrived from https: / / ptgustavlandauer. files.wordpress.com/2014/09/etienne-balibar-spinoza-fromindividuality-to-transindividuality.pdf

Balibar, É. (1998). Spinoza and politics. (P. Snowdon, Trans.). New York: Verso.

Dahlbeck, J. (2015). Educating for immortality: Spinoza and the pedagogy of gradual existence. Journal of Philosophy of Education, 49(3), 347-365.

Deleuze, G. (1988). Spinoza, Practical Philosophy. (R. Hurley,

Trans.). City Lights: San Francisco. Deleuze, G. (1990).

Expressionism in philosophy: Spinoza. New York, NY: Zone Books.

Donovan, S. (2009). Rereading Irigareay's Spinoza. In M. Gatens (Ed.), Feminist interpretations of Benedict Spinoza (pp.165-187). London: Routledge.

Foley, A. (1973). A bolton childhood. Manchester, NH: Manchester University ExtraMural Department.

Gatens, M. (2009). The politics of the imagination. In M. Gatens (Ed.), Feminist interpretations of Benedict Spinoza (pp. 189-209). London: Routledge.

Gatens, M., \& Lloyd, G. (1999). Collective imaginings: Spinoza past and present. London: Routledge.

Grassi, P. (2009). Adam and the serpent: Everyman and the imagination. In M. Gatens (Ed.), Feminist interpretations of Benedict Spinoza (pp. 145153). London: Routledge.

Heller, R. \& Bauman, S. (1985). The Women of Summer, a documentary

film, directed by Susan Baumer, produced by Rita Heller.

Hollis, K. L. (2004). Liberating voices: Writing at the Bryn Mawr summer school for women workers. Carbondale: Southern Illinois University Press.

James, S. (2011). I-Susan James: Creating rational understanding:

Spinoza as a social epistemologist. Aristotelian Society Supplementary Volume, 85, 181-199.

Lloyd, G. (1996). Spinoza and the ethics. London: Routledge.

Lloyd, G. (1998). Spinoza and the education of the imagination. In A. Rorty (Ed.), Philosophers on education: New historical perspectives (pp. 156-171). London: Routledge.

Negri, A. (1991). The savage anomaly: The power of Spinoza's 
metaphysics and thought. (M. Hardt, Trans.). Minneapolis: University of Minnesota Press.

Plummer, K. (2001). Documents of Life (2nd ed.). London: Sage.

Read, J. (2015). The politics of transindividuality. Boston, MA: Brill.

Rorty, A. (1987). The two faces of Spinoza. Review of Metaphysics, 41(2), 299-316.

Rorty, A. (2009). Spinoza on the pathos of idolatrous love and the hilarity of true love. In M. Gatens (Ed.), Feminist interpretations of Benedict Spinoza (pp. 65-85). London: Routledge.

Ruddick, S. (2010). The politics of affect: Spinoza in the work of Negri and Deleuze. Theory, Culture and Society, 27(4), 21-45. Samuel, R., MacColl, E., \& Cosgrove, S. (1985). Theatres of the left, 1880-1935: Workers' theatre movements in Britain and America. London: History Workshop Series.

Smith, W. H. 1929. Women workers at the Bryn Mawr summer school. New York, NY: Affiliated Summer Schools for Women Workers in Industry and American Association for Adult Education.

Spinoza, B. (1982). Ethics. (S. Feldman Ed., S. Shirley,Trans.). Indianapolis, IN: Hackett.

Spinoza, B. (2002). Ethics. (A. Boyle, Trans.). London: Everyman.

Tamboukou, M. (2003). Interrogating the'emotionalturn': making connections with Foucault and Deleuze. European Journal of Psychotherapy \& Counselling, 6(3), 209-223.

Tamboukou, M. (2015). Sewing, Fighting and Writing: Radical Practices in Work, Politics and Culture. London: Rowman and Littlefield.

Tamboukou, M. (2017). Women workers' education, life Narratives and politics: Geographies, histories, pedagogies. Basingstoke: Palgrave Macmillan.

Taylor, C., \& Hughes, C. (Eds.). (2016). Posthuman research practices in education. Basingstoke: Palgrave. 